\title{
Utilization of Garlic and Kaemfiera on the Strength of Fungi Growth in Sardine Fish 'Pedetan' (Sardinella lemuru)
}

\author{
Ni Made Ayu Suardi Singapurwa ${ }^{1}$, I Putu Candra ${ }^{2}$ \\ \{suardani@gmail.com ${ }^{1}$,candra_atsiri@yahoo.co.id ${ }^{2}$ \} \\ Department of Food Science and Technology, Warmadewa University Denpasar-Bali, \\ Indonesia $^{12}$
}

\begin{abstract}
Sardine fish 'Pedetan' is one of the traditional foods in the area of Jembrana Regency, Bali. During the process of storing 'Pedetan', they are often damaged by fungi that pollute the Pedetans. This study aims to determine the use of garlic and kaemfiera on the growth of fungi that can contaminate Pedetan. The results showed that the use of garlic and kaemfiera can inhibit fungal growth. The making of sardine fish sprouts using garlic spices can inhibit the growth of fungi with a inhibition zone of $21.15 \mathrm{~mm}$ and kaemfiera can inhibit the inhibition zone by $25.45 \mathrm{~mm}$. Garlic and kaemfiera can inhibit fungal growth because they contain bioactive compounds that can be antimicrobial.
\end{abstract}

Keywords: Garlic, kaemfiera, Sardine fish Pedetan

\section{Introduction}

Pedetan is one of the traditional Balinese spicy dried fish food products processed by the community in the Jembrana Regency area of Bali Province. The community processes and extends the shelf life of the sardine by processing it into food products that can be stored longer, which is commonly referred to as Pedetan. Pedetan made from sardine, salt and spices, is dried in the sun for two to three days, then stored at room temperature [1].

Damage to dry fish can occur during storage and during distribution in marketing. Some of the damage that may occur to dry fish include: Damage due to microorganisms, such as bacteria and fungi, Damage caused by enzymes, both enzymes derived from fish and from bacteria. Seasonings used in the process of making 'Pedetan' sardine fish can be used as one of the ingredients to damage dried fish processed products. Garlic contains active Allicin compounds which have anti-microbial activity [2].

The diverse processing of Pedetan in each village makes it a distinctive characteristic for Pedetan producing villages. This also affects the existence of different food quality and safety. Therefore the products produced are not uniformly quantitative or qualitative [1], with a lasting power that varies, only 2-4 weeks, making it difficult to standardize. Therefore it is necessary to develop traditional processing with several improvement efforts by applying basic feasibility to food processing [3]. Quality management and safety aspects of raw materials and products need to be studied for business development, product development and marketing of packaging $[4 ; 5]$. 


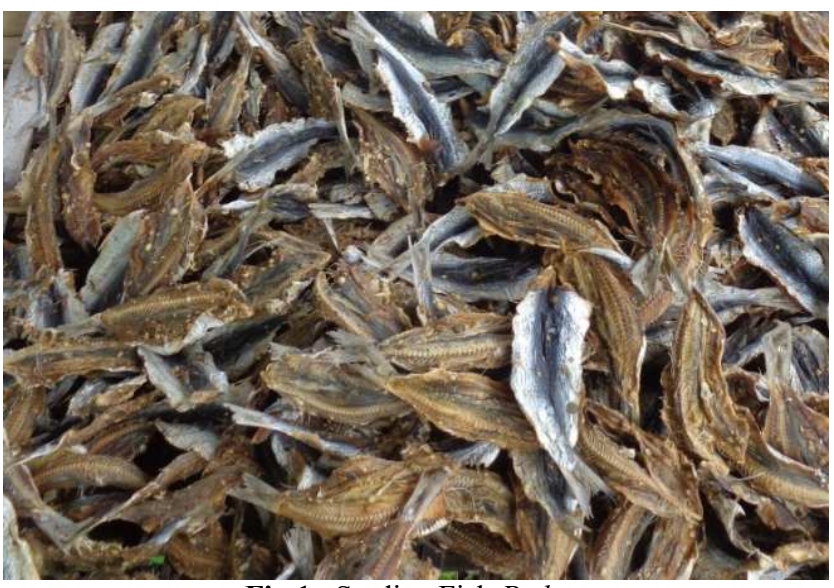

Fig 1. Sardine Fish Pedeta

Processing of sardine fish cakes is done by producers with several different seasoning formulations. In general, people use a mixture of several different spices depending on the tastes of the local people. The spices that are always used in making Pedetan are kaemfiera and garlic. Several studies have shown that garlic has antimicrobial effects on gram-positive and gram-negative bacteria, fungi, and parasites [4]. As an antimicrobial, garlic can inhibit the growth of Salmonella enteritidis and Staphylococcus aureus [5]. The kaemfiera rhizome extract (Kaempferia galanga L.) can inhibit the growth of Escherichia coli [5]. The inhibition of kaemfiera extract (Kaempferia galanga L.) on Trichophyton tagrophytes and Cryptococcus neoformans with diffusion method showed that kaemfiera extract (Kaempferia galanga L.) was able to inhibit the growth of those with a minimum extract inhibitory concentration of $0.15 \%$ against Trichophyton mentagrophytes and 2\% against Cryptococcus neoformans [6]. Therefore it is necessary to conduct research to analyze the ability of garlic and kaemfiera in inhibiting mold in sardine fish Pedetan.

\section{Research Methodology}

\subsection{Sampling and Extraction Methods}

Sampling of lemuru fish sprouts and observations on seasoning used during the processing were carried out in 10 Pedetan producing villages. Furthermore, the Pedetan sample was weighed $1 \mathrm{~g}$ and a dilution series from 10-1 to 10-6 was carried out. Furthermore, at 10-6 dilutions, each sample was taken $100 \mu \mathrm{l}$ of suspension and put into $10 \mathrm{ml}$ of PDA media in a Petri dish and incubated at room temperature for 2 days.

Garlic and kaemfiera are dried air for 2-3 days until a constant weight is obtained. Dry samples are blended until they become powder. Dry powder samples of $1000 \mathrm{~g}$ were macerated with $2000 \mathrm{ml}$ ethanol $70 \%$ for 24 hours 3 times. The obtained filtrate is combined and evaporated with a rotary vacuum evaporator, so that crude ethanol extracts are obtained. The crude extract is then used to observe the inhibition of fungi. 


\section{Result and Discussion}

\subsection{Results Fungi isolation in sardine fish Pedetan}

The results of observations on each sample in each village of Pedetan producer centers showed fungi contamination in the lemuru fish Pedetan products as shown in Table 1. There were no contamination caused by Salmonella, Vibrio cholera, Staphylococcus aureus and Escherichia coli in sardine fish. fresh and dried fish, while total microbes in Pedetan are 1.56 $\mathrm{x} 10^{7} \mathrm{CFU} / \mathrm{g}$ [7].

Table 1. Moldpopulation from sardine fish Pedetan

\begin{tabular}{lc}
\hline \multicolumn{1}{c}{ Sample location } & $\begin{array}{c}\text { Average mold population } \\
(\mathrm{CFU} / \mathrm{g})\end{array}$ \\
\hline Perancak & $6,5 \times 10^{4}$ \\
Pengambengan & $4,3 \times 10^{5}$ \\
Baler Bale Agung & $9,3 \times 10^{5}$ \\
Air Kuning & $7,5 \times 10^{5}$ \\
Baluk & $9,6 \times 10^{5}$ \\
Pangkung Gayung & $9,9 \times 10^{5}$ \\
Melaya & $8,3 \times 10^{5}$ \\
YehSumbul & $3,4 \times 10^{5}$ \\
Banyubiru & $8,1 \times 10^{4}$ \\
Berangbang & $5,6 \times 10^{4}$ \\
\hline
\end{tabular}

Table 2. The composition of the spices of lemuru fish in each village

\begin{tabular}{rll}
\hline No & \multicolumn{1}{c}{ Village } & \multicolumn{1}{c}{ Sardine fish Pedetan spicy } \\
\hline 1. & Perancak & garlic, coriander, galingale, turmeric, vinegar, ginger, salt. \\
2. & Melaya & garlic, coriander, onion, brown sugar, acid, salt. \\
3. & Baler Bale Agung & garlic, coriander, turmeric, salt. \\
4. & Berangbang & garlic, coriander, kaemfiera, salt. \\
5. & Baluk & coriander, chili, salt. \\
6. & Kaliakah & garlic, coriander, chili, brown sugar, salt \\
7. & Pengambengan & garlic, coriander, turmeric, vinegar, sour, sugar, salt. \\
8. & Yeh Sumbul & coriander, sugar, salt. \\
9. & Banyu Biru & Coriander, vinegar, sugar, salt. \\
10. & Air Kuning & garlic, coriander, turmeric, kaemfiera, salt. \\
\hline
\end{tabular}

There are differences in the number of fungi populations that contaminate sardine fish Pedetan [8]. The difference in the number of fungi is due to differences in seasoning and sanitation hygiene during the traditional processing of Pedetan food and product packaging [4; 5]. The types of herbs used by producers in each village are as listed in Table 2. Based on Table 2, it can be seen that the use of garlic and kaemfiera spices can inhibit the growth of fungus that pollute Pedetan. 


\subsection{Results Testing of the inhibition of a single seasoning against fungi}

The results of the anti-fungal activity test of seasoning extracts on fungi showed that garlic and kaemfiera were able to inhibit fungi growth. with inhibition zone diameters of 21.15 $\mathrm{mm}$ and $25.45 \mathrm{~mm}$, respectively (Table 3 and Figure 2). Several studies have shown that the spices used for Pedetan have anti-bacterial and antibacterial activity [8]. Garlic has an antimicrobial effect on Gram-positive and Gram-negative bacteria, fungi, and parasites [4]. Garlic extract can inhibit the growth of fungi Candida albicans [9]. Efforts are needed to improve the composition of the Pedetan spices so that as much as possible can suppress the contaminant fungipopulation in the Pedetan.

Table 3. Test the activities of antifungi herbs for mold

\begin{tabular}{lc}
\hline Spicy & Inhibit (mm) \\
\hline Garlic & 21,15 \\
Kaemfiera & 25,45 \\
\hline
\end{tabular}

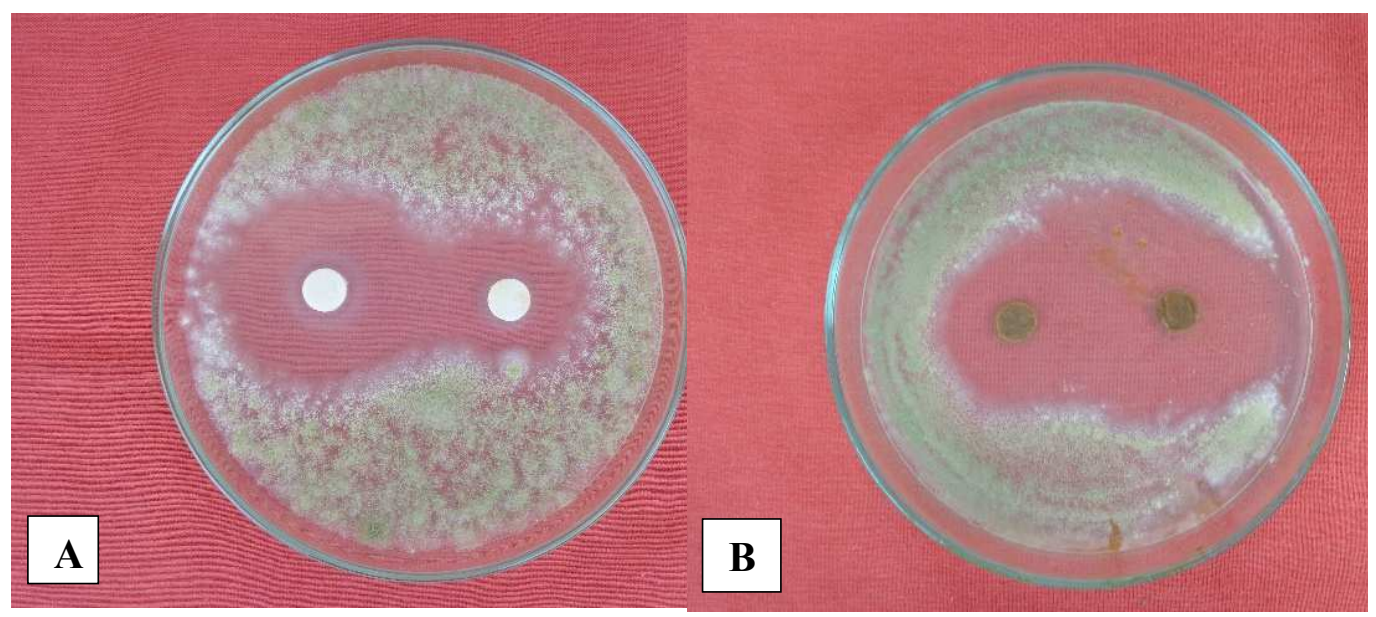

Fig 2. A. Inhibitory of Garlic Extract against fungi. B The inhibitory of Kaemfiera extract against fungi

Garlic contains more than 200 chemical components. Some of the important ones are volatile oils containing sulfur (allicin, alliin, and ajoene), peptides, steroin, terpenoids, flavonoids, phenols, 17 amino acids, glycosides, argini and enzymes (allinase, peroxidase, and myrosinase) [10]. Allicin is useful as an antibiotic and causes a distinctive smell of garlic. Ajoene contributes to the action of garlic anticoagulants. Garlic has a high concentration of sulfur components. Tiosulfinate which contains allicin, is an active substance of garlic. Allicin is formed when alliin, an amino acid containing sulfur, contacts the allinase enzyme when raw garlic is cut, crushed or chewed. Dry garlic preparations containing alliin and alliinase must be packaged in the form of enteric coating to be effective because stomach acid can damage the alliinase enzyme, which in turn will inhibit allicin formation. Because alliinase is deactivated by heat, cooked garlic has less medical value [11]. 
When garlic is crushed, chewed, or when dehydrated and exposed to water, the vacuolar alliinase enzyme rapidly lyses cytosolic cysteine sulfoxide (alliin) to form cytotoxic and odiferous alkyl alkane-thiosulfinate [4]. The component that is formed temporarily, allicin, an oily and colorless liquid, is $70-80 \%$ of thiosulfinate. Typically alliin is converted to allicin by alliinase. Allicin is a sharp and highly unstable component that breaks down sulfides including ajoene and dithiins.

Chemical garlic is quite complex and has a mechanism of protection against microorganisms. The main sulfur constituents found in intact garlic are gamma-glutamyl-S-alk (en) yl-L-cysteines and S-alk (en) yl-L-cysteine sulfoxide, including allicin [12]. When whole garlic is stored at cool temperatures, alliin accumulates naturally. On average, one complete form of garlic contains $0.9 \%$ gamma-glutamylcysteine and up to $1.8 \%$ alliin. The health benefits of garlic arise from various components that might work synergistically. The chemical content of the garlic complex produces various types of preparations due to variations in processing.

The chemical content of garlic is very complex. Garlic contains water $(58.58 \%)$, carbohydrate as fructan $(33,068 \%)$, sugar $(1 \%)$, crude fiber $(2.1 \%$, fat $(0.5 \%)$, protein $(6.39 \%)$, beta carotene $(5 \mu \mathrm{g})$ Thiamin $(0,2 \mathrm{mg})$, Riboflavin $(0.11 \mathrm{mg})$, Pantothenic acid $(0.596 \mathrm{mg})$, Flae $(3 \mu \mathrm{g})$, Vitamin C (31.2 mg), Calcium (181 mg), Magnesium $25 \mathrm{mg}$ ), Phosphorus (401 $\mathrm{mg}$ ), Sodium ( $17 \mathrm{mg})$, Zinc (1.16 mg), Manganese (1,672 mg), selenium (14.2 $\mu \mathrm{g})$. The main content of organosulfur in garlic is 1 L-glutamyl-S-alkyl-L-cysteine and alkyl-L-cysteine sulfoxide. The allil cysteine sulfoside (alliin) content is $80 \%$ of cysteine sulfoxide in garlic $[10]$.

The largest component of garlic tuber is alliin (S-allilsistein sulfoxide), which is equal to $10 \mathrm{mg} / \mathrm{g}$ of fresh garlic or $30 \mathrm{mg} / \mathrm{g}$ of dry weight. When garlic is crushed, alliin substances which actually don't smell will break down. With the boost of the alinase enzyme, alliin breaks down into allicin, ammonia, and pyruvic acid. The sharp smell of allicin is caused by sulfur content. This distinctive aroma increases when the sulfur (sulfur) in allicin is flown by ammonia into the air, because ammonia is volatile. When dry garlic is dissolved in a nonacidic solution, the L-cysteine sulfoxide will change to thiosulfinate which is a component of the scent of fresh garlic.

Another component of garlic, which is allil, is most commonly in the form of Diallyl disulfide. Allysin is the active compound of alliin which is formed by the enzyme allinase when garlic is cut. Another degradation product from Allin is Ajoene which can inhibit thrombotic synthesis through inhibition of the synthesis of the cyclo-oxygenase and lipoxygenase enzymes. Selenium in garlic plays an active role as an antioxidant and is part of the glutathione peroxidase enzyme. Garlic contains several compounds, namely: garlic homogenate (allicin), heat treated garlic (alliin), garlic powder (alliin), garlic extract (S-allyl cysteine), garlic oil (Diallyl disulfide), oil extract garlic (2-vinyl-4-H-1, 3-dithin), the main metabolite of raw garlic in the blood (Allyl mercapton) [13].

The kaemfiera rhizome (Kaempferia galanga L.) is an economically valuable plant that is so high that it is widely cultivated and used as a food spice or for the treatment of one of the anti-fungi. In the area of South Kalimantan the community uses the kaemfiera rhizome as a medicine by making drinks in the form of herbal medicine, attaching the lungs of galingale to the parts of the body that are treated or consuming directly the kaemfiera rhizome to treat canker sores [14].

The active ingredient Spices are an additional ingredient for the people of Indonesia and are widely used as a spice in traditional foods. Spices are plants or parts of plants that can be used in fresh or dry forms. Most spices have dual usability, namely to improve the aroma and 
taste of the products produced and used for the ingredients of traditional medicines. Spices used in daily food processing with ordinary concentrations cannot preserve food but at this concentration spices can help other ingredients that can prevent microbial growth in food. The effect of inhibiting microbial growth by a type of spice is characteristic. Each type of antimicrobial compound has a unique inhibitory ability for a particular type of microbe. Spices that are known to have strong antimicrobial activity are onion, garlic, red chili, ginger, turmeric and galangal [15].

Spices are also used as food preservatives in various countries, including meat. The activity of spices as a preservative is caused by its function as an antioxidant and antimicrobial. Cinnamon, cloves and garlic will reduce the growth of Escherichia coli 0157: H7 in meat at the middle level. Natural ingredients that can be useful as antimicrobials are likely to be quite effective against fungi and contaminants in foods containing mycotoxins or can minimize the formation of microbes. The function of preservatives is to stop or reduce the speed of development of microorganisms, while antioxidants inhibit chemical changes in fat or oil becomes rancid and damaged. Traditionally the use of natural preservatives, especially fresh spices, is a seasoning that is mixed with meat or processed meat, or by soaking or applying it. Its use is usually not in the form of a single ingredient, but is a mixture of several types of spices.

Groups of polyphenols in foods are phenolic acids (hydroxybenzoic and hydroxycinnamic acids), flavonoids (flavonols, flavones, isoflavones, flavonones, flavanols and anthocyanidins), and lignans. Other groups of polyphenols are coumarin and tannin: the coumarin is a phenolic compound derived from sinamat and tannin is a polyphenol compound such as proanthocyanidins and gallic acid with a molecular weight of more than 500. A large number of polyphenols in nature are influenced by environmental factors, both biotic and abiotic, Polyphenols are found in various plants, and are found in herbs and spices, especially in their dry form, generally containing relatively higher polyphenols compared to other polyphenols, such as broccoli, dark chocolate, red, blue and purple fruit, grapes and onion. The group of polyphenols in herbs and spices are phenolic acids and flavonoids, especially flavones and sub-flavonol groups. Some other herbs such as parsley (Petroselinum crispum), cinnamon (Cinnamomum aromaticum Nees) ginger (Zingiber officinale), turmeric (Curcuma longa L.) also contain other groups of polyphenols, namely furanocoumarins (parsley), hydroxycoumarins (cinnamon), hydoxyphenylpropenes (ginger), curcuminoid (turmeric) [16]

\section{Conclusion}

Garlic and kaemfiera can inhibit the growth of fungi that can contaminate Pedetan. The making of sardine fish using garlic spices can inhibit the growth of fungi with a inhibition zone of $21.15 \mathrm{~mm}$ and kaemfiera can inhibit the inhibition zone by $25.45 \mathrm{~mm}$. Garlic and kaemfiera can inhibit fungal growth because they contain bioactive compounds that can be antimicrobial.

\section{Acknowledgments}

The author conveyed his gratitude to the Warmadewa University Community Research Institute for funding the 2018 Institutional Grant Research. 


\section{References}

[1] Singapurwa, N.M.A.S., N. M. Darmadi, A.A.M. Semariyani.: Characteristics of Traditional Food Pedetan in Jembrana Regency. International Journal of Advanced Science Engineering Information Technology. Vol. 4(2). pp. 68-74 (2014)

[2] Syifa, N., S.H. Bintari, D. Mustikaningtyas.: Uji efektivitas ekstrak bawang putih (Allium sativum Linn.) sebagai antibakteri pada ikan bandeng (Chanos chanos Forsk.) segar. Life Science. Vol. 2(2). pp. 71-77 (2013)

[3] Singapurwa, N.M.A.S., A.A.M. Semariyani, I.P Candra.: Identification of the Implementation of GMP and SSOP on the Processing of the Balinese Traditional Food Sardine Pedetan. International Research Journal of Engineering, IT and Scientific Research. Vol. 3(3). pp. 17-26 (2017)

[4] Biradar S.M., G.D. Mote, G.V. Sutar.: Extraction of Garlic and Enhacing Antibiotic Activity of Allicin. International Journal of Phytotherapy Research. Vol. 4(2). pp. 16-22 (2014)

[5] International Journal of Phytotherapy Research.: Antimicrobial Activity of Garlic (A. sativum L.) Against Salmonella enteritidis and Staphylococcus aureus. Contemporary Agriculture / Savremena Poljoprivreda. Vol. 63(3). pp. 224-231 (2014)

[6] Gholib, D.: Uji daya antifungi ekstrak etanol rimpang kencur (kaemfera galanga 1.) terhadap pertumbuhan jamur trichophyton verrucosum secara in vitro. Seminar Nasional Teknologi Peternakan dan Veteriner. pp. 865 - 869 (2011)

[7] Singapurwa, N.M.A.S., A.A.M. Semariyani, I.P Candra.: Microbial Contamination in Traditional Food Processing Pedetan. Proceeding The International Conference in Bioscience 2016, Denpasar. pp. 26-27 (2016)

[8] Singapurwa, N.M.A.S., D.N. Suprapta, I B.W. Gunam, I G.N.A.S. Wirya, K.Khalimi.: Identification of Contamination Fungi on Pedetan, an dry fish product of Lemuru. Journal of Biology, Agriculture and Healthcare. Vol. 8(6). pp. 75-82 (2018)

[9] Khaira, N., Misrahanum, Idroes, R., Bahi, M., Khairan.: Pengaruh kombinasi ekstrak petroleum eter bawang putih (allium sativum linn) dengan vitamin $\mathrm{C}$ terhadap aktivitas Candida albicans. (2016)

[10] Tesfaye, A. and W. Mengesha.: Traditional Uses, Phytochemistry and Pharmacological Properties of Garlic (Allium sativum) and its Biological Active Compounds. International Journal of Scientific Research in Science, Engineering and Technology. Vol. 1(5). pp. 142-148 (2015)

[11] Hernawan, U.E dan A.D. Setyawan.: Senyawa Organosulfur Bawang Putih (Allium sativum L.) dan Aktivitas Biologinya. Jurnal Biofarmasi. Vol. 1(2). pp. 65-76 (2003)

[12] Al-Dulimyi, E.M.K., F.M. Abid, M. J. A. Al-Gani.: Determination of Active Ingredients (Alliin \& Allicin) in Different species of Garlic Extracts by Using High Performance Liquid Chromatography. Diyala Journal For Pure Sciences. Vol. 9(2). pp. 70-81 (2013)

[13] V Singla, R Bhaskar, R Bhaskar: Garlic : A Review. International Journal of Drug Formulation \& Research. Vol. 2(2). pp. 94-110 (2011)

[14] Kuntorini, E.M.: Botani Ekonomi Suku Zingiberaceae sebagai Obat Tradisional oleh Masyarakat di Kotamadya Banjarbaru. Bioscientiae. Vol. 2(1). pp. 25-36 (2005)

[15] Rahayu, W.P.: Aktivitas antimikroba Bumbu Masakan Tradisional Hasil Olahan Industri Terhadap Bakteri Patogen dan Perusak. Bul Teknologi dan Industri Pangan. Vol. 9(2). pp. $42-48$ (2000)

[16] Opara, E.I., and M. Chohan.: Culinary Herbs and Spices: Their Bioactive Properties, the Contribution of Polyphenols and the Challenges in Deducing Their True Health Benefits. Int. J. Mol. Sci. Vol. 15. pp. 19183-19202 (2014) 